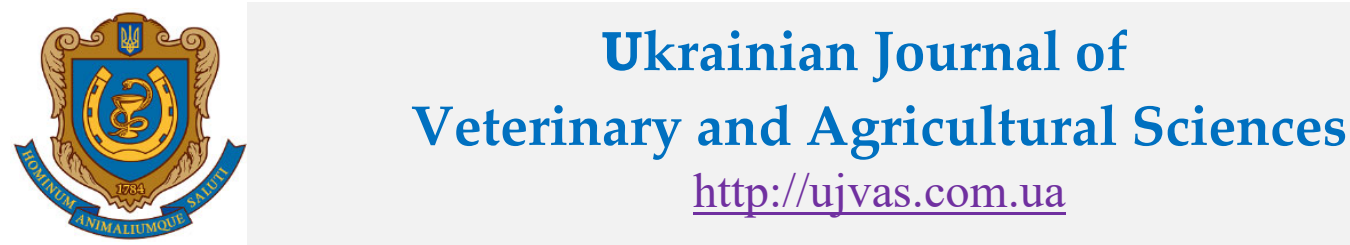

Stepan Gzhytskyi National University of Veterinary Medicine and Biotechnologies Lviv

original article $\mid$ UDC 619:612.129:636.085.8:636.4 $\mid$ doi: 10.32718/ujvas4-2.07

Volume 4

Number 2

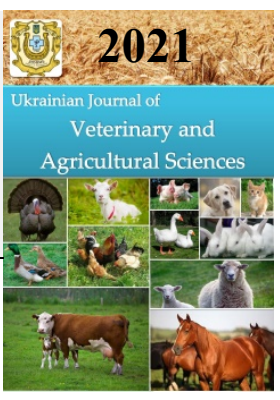

\title{
System of antioxidant protection of the body of piglets under the action of feed additive "Butaselmevit-plus"
}

\author{
T. V. Martyshuk ${ }^{1}$, B. V. Gutyj ${ }^{1}$, V. I. Khalak ${ }^{2}$

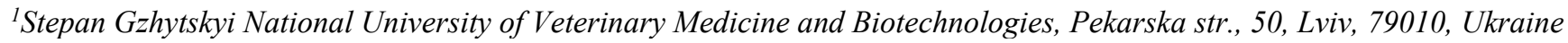 \\ ${ }^{2}$ State Institution "Institute of Grain Crops of NAAS", V. Vernadskoho str., 14, Dnipro, 49027, Ukraine
}

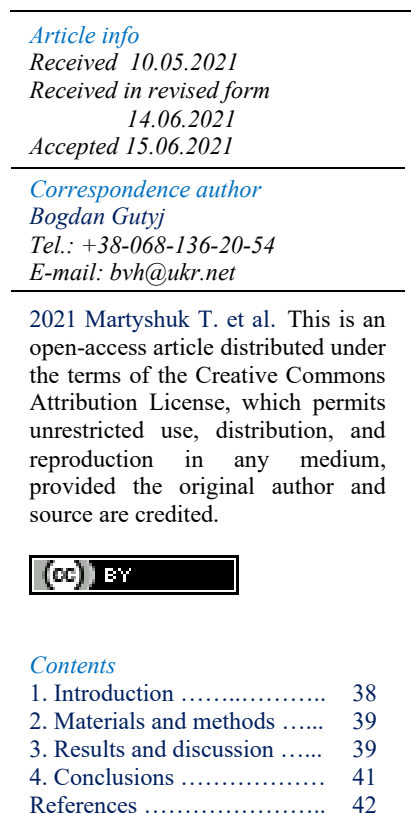

References ..................... 42

\begin{abstract}
The aim of the study was to investigate the effect of the feed additive "Butaselmevit-plus" on the state of the antioxidant defense system of piglets during weaning. The experiments were conducted on the basis of the LTD "KOSHET" Mukachevo district of Zakarpattia region. Two groups of piglets were formed - control and experimental, in the amount of 10 individuals in each group, selected on the principle of analogs - age, breed and body weight. Animals were fed according to the norms for this age of pigs. On the 28th day of life, the piglets were weaned from the sow and regrouped from different nests for further maintenance during fattening and rearing with a change in the structure of the diet, which served as technological stress for the animal's body. Piglets of the experimental group, from 21 to 40 days of age, were additionally fed the feed additive "Butaselmevit-plus" at a dose of $100 \mathrm{mg} / \mathrm{kg}$ body weight per day. The material for the study was blood, which was taken in the morning before feeding the animals by puncture of the cranial vena cava for 20 days of life (the period before weaning), for 25 days of life (the period before weaning), for 30 days of life ( 2 days after weaning), for 35 days of life ( 7 days after weaning), 40 days of life (12 days after weaning). It is proved that feeding piglets feed additive "Butaselmevit-plus" enhanced the antioxidant status of piglets after weaning. It was found that under conditions of technological stress, the use of feed additive "Butaselmevit-plus" in the amount of $100 \mathrm{mg} / \mathrm{kg}$ body weight per day improves the antioxidant defense of the body, as evidenced by an increase in blood 35-day-old piglets superoxide dismutase activity by $26.7 \%(\mathrm{P}<0.001)$, catalase - by $39.5 \%(\mathrm{P}<0.001)$, glutathione peroxidase - by $51.7 \%$ $(\mathrm{P}<0.05)$, glutathione reductase - by $52.9 \%(\mathrm{P}<0.05)$, the content of reduced glutathione - at $58.3 \%(\mathrm{P}<0.001)$. These results confirm the effectiveness of the use of milk thistle, methionine, selenium, and vitamins $\mathrm{A}, \mathrm{E}$, and $\mathrm{D}_{3}$ in the feed additive "Butaselmevit-plus" to piglets in the period before and after weaning to activate the protective systems of their body.
\end{abstract}

Key words: piglets, stress, antioxidant defense system, vitamins, selenium, methionine.

\section{Citation:}

Martyshuk, T. V., Gutyj, B. V., \& Khalak, V. I. (2021). System of antioxidant protection of the body of piglets under the action of feed additive "Butaselmevit-plus". Ukrainian Journal of Veterinary and Agricultural Sciences, 4(2), 38-43.

\section{Introduction}

The introduction of intensive technologies in pig breeding involves early weaning of piglets from sows, which leads to stress, metabolic homeostasis, and increased free radical processes in the body. During weaning, nonspecific changes occur in the body of piglets, which lead to depletion of antioxidant potential and reduced immunobiological reactivity. This is due to the low level of adaptive processes in the body and immunodeficiency, which leads to a high degree of disease and a high mortality rate (Ahmed et al., 2014; Kramarenko et al., 2018; 2019; Martyshuk \& Hutyi, 2021; Snegin et al., 2021).

It is known that piglets are able to digest only the protein and fat of sow's milk, which is their main food until the 20th day (Martyshuk et al., 2019; Han et al., 2019; Leskiv et al., 2021). Early weaning (days 18-31) of piglets allows the sow to be used more intensively (Khalak \& Gutyj, 2020; Khalak et al., 2020). However, weaning piglets from sows is a strong stress factor that negatively affects metabolism and physiological functions in their body. The greatest stress response in piglets occurs when groups are formed for rearing from different nests immediately after weaning from sows at 26 days of age (Jayaraman \& Nyachoti, 2017; Chen et al., 2018; Martyshuk et al., 2020). In the first days after weaning, the piglets are affected by a number of adverse factors: change of feeding, transition to another room with a different microclimate, keeping in groups of 20-25 animals from different nests, etc. (Ariza-Nieto et al., 2011; Masiuk et al., 2018; Lukashchuk et al., 2020). During this period, piglets do not fully stabilize the adaptive defense mechanisms and they are extremely sensitive to stress (Hedemann \& Jensen, 2004; Bulter et al., 2006; Masiuk et al., 2017; Czech et al., 2018; Lykhach et al., 2020).

To prevent the negative effects of stress, along with providing the necessary conditions for care and maintenance, in recent years have successfully developed effective and cost-effective new complex drugs (De Lange et al., 
2010; Jacela et al., 2010; Heo et al., 2012; Holman \& Chénierab, 2015; Gutyj et al., 2017; Kiczorowska et al., 2017; Fedak et al., 2018). The use of substances of natural origin is especially promising in this direction. There are some reports in the literature on the stimulating effect of milk thistle, fat-soluble vitamins, selenium, and butaphosphane on the activity of the immune and antioxidant systems in animals. However, these studies are fragmentary, so there is a need for detailed study and generalization of this topic. In particular, it is extremely important to comprehensively study the effect of these substances on the antioxidant potential and immune function of animals under oxidative stress. Carrying out research in this aspect is relevant because it opens the way to the development of scientifically sound methods of managing adaptive and protective processes in animals, in particular - In piglets at weaning from sows.

The aim of the study was to investigate the effect of the Butaselmevit-Plus feed additive on the antioxidant status of piglets during weaning.

\section{Materials and methods}

The experiments were performed on the basis of LLC "KOSHET" Mukachevo district, Transcarpathian region. Two groups of pigs were formed - the control (C) and the experimental $(\mathrm{E})$, in the number of 10 individuals in each group, selected on the basis of analogues - age, breed and body weight. In the suckling period, pigs were kept under sows in special machines, had constant access to the mother, and from 5 days of age - free access to concentrated feed. Feeding of animals was carried out according to the norms for this age of pigs. Clinical and physiological examinations of piglets were conducted prior to the search. They took into account their general state and activity when eating feed. On the 28th day of life, piglets were weaned from the sow and regrouped from different nests for further retention and rearing, with changing dietary structure, which served as technological stress for the animal organism. Beginning at the age of 5 days, piglets of all groups were fed pre-stern compound feed. The piglets of the experimental group, from 21 to 40 days of age, were additionally fed the feed additive "Butaselmevit-plus" at a dose of $100 \mathrm{mg} / \mathrm{kg}$ of body weight per day.
The research material was blood collected in the morning prior to animals feeding by puncture of the cranial vena cava on $20^{\text {th }}$ day of life (period before weaning), on 25 th day of life (period before weaning), for 30 days of life ( $2^{\text {nd }}$ day after weaning), on $35^{\text {th }}$ day of life (7 days after weaning), on $40^{\text {th }}$ day of life ( $2^{\text {nd }}$ day after weaning).

The activity of glutathione peroxidase (GP, E.C.1.11.1.9) and glutathione reductase (GR, E.C.1.6.4.2) was determined by the method of V.V. Lemeshko et al. (1985); catalase activity (CT; E.C.1.11.1.6) - by the method of M. A. Korolyuk (1988); superoxide dismutase activity (SOD, E.C.1.15.1.1) by the method of E. E. Dubinina et al. (1983).

Analysis of the research results was performed using the Statistica 6.0 software package. Probability differences was evaluated by Student's t-criterion. The results were considered reliable at $\mathrm{P} \leq 0.05$.

\section{Results and discussion}

The efficiency and profitability of intensive production of livestock products largely depend on the state of health and the ability of animals to withstand the effects of many environmental factors. According to the literature, it is known that in the body of piglets after birth intensifies the processes of lipid peroxidation (Lukashchuk et al., 2020; Stoyanovskyy et al., 2020; Martyshuk \& Hutyi, 2021). This is due to the low activity of almost all studied indicators of the antioxidant defense system. Thus, on the basis of our research, low activity of enzymes of the antioxidant system was established, which are the first to neutralize free radicals, preventing the development of oxidative stress. In the study of superoxide dismutase activity in the blood of piglets, it was found that it was the lowest in 20-day-old piglets (Fig. 1). Subsequently, in the piglets of the control group, the activity of this enzyme increased by $11.6 \%$. indicating the provision of the body of piglets with the necessary nutrients to form all parts of the antioxidant defense system and reduce the impact of negative stressors during this period. After weaning the piglets at the age of 28 days, a decrease in enzyme activity was found. In 40-day-old piglets, superoxide dismutase activity probably increased by $6.4 \%$.

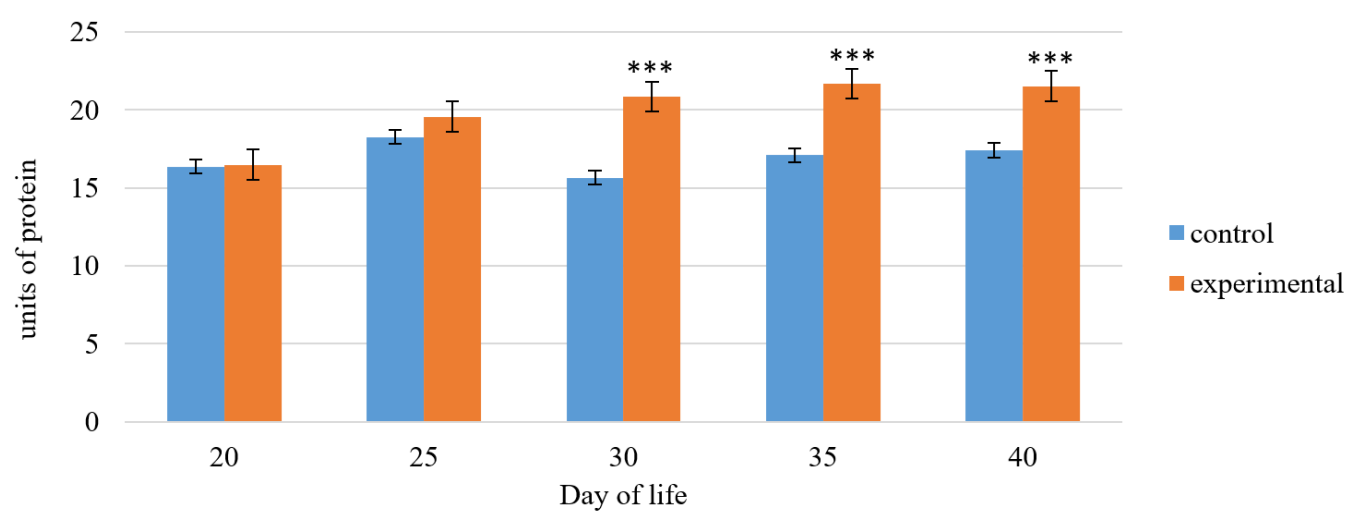

Fig. 1. Superoxide dismutase activity in the blood of piglets under the action of feed additive "Butaselmevit-plus"

Given the high-stress sensitivity of piglets, their low resistance and susceptibility to metabolic disorders on the one hand, and stress during rearing, non-physiological housing conditions, and insufficiently balanced feeding - on the other, it becomes clear the need to use biologically active substances to increase resistance and immunobiological reactivity. their body. Therefore, to increase the antioxidant status of piglets, we used a feed additive "Butaselmevitplus", which contains a mixture of ground fruits of milk thistle, methionine, tocopherol acetate, sodium selenite, and ascorbic acid. 
It was found that when feeding the feed additive "Butaselmevit-plus" in piglets on the 25 th day of life, the activity of superoxide dismutase was slightly higher than in the control group. A probable increase in the activity of this enzyme was observed on the 30th day of life, where, according to the control group, it increased by $33.1 \%$. Subsequently, in the serum of piglets of the experimental group, the activity of superoxide dismutase was higher by 26.7 and $23.6 \%$ relative to the control group.

Superoxide dismutase in the blood, as the primary antioxidant, maintains and controls the level of free radicals, thus creating the conditions for normal use of the body's oxygen environment (Varkholiak et al., 2021; Vasylyev et al., 2021).
In addition, SOD successfully deactivates reactive oxygen species, after the decomposition of which hydrogen peroxide is formed. For this reason, SOD always functions together with catalase, which is involved in the detoxification of the non-radical active form of oxygen $-\mathrm{H}_{2} \mathrm{O}_{2}$ (Stybel et al., 2021; Sachuk et al., 2021; Slobodian et al., 2021).

It was found that on the 25 th day of life the activity of catalase in the blood of the control group of piglets increased by $7.9 \%$, while in the experimental group - by $10.8 \%$ compared with the initial values. After weaning the piglets, the activity of this enzyme in the blood of 30 -dayold piglets in the experimental group was higher by $14.1 \%$ compared with the control group (Fig. 2).

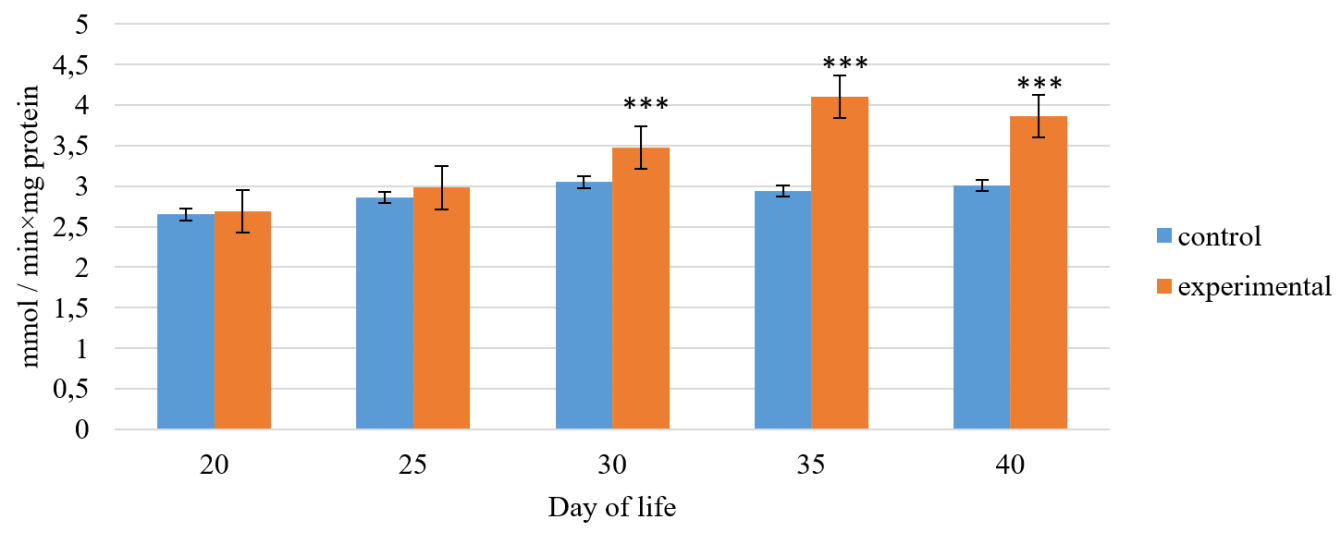

Fig. 2. Catalase activity in the blood of piglets under the action of feed additive "Butaselmevit-plus"

On the 35 th day of the life of piglets, a decrease in catalase activity was found in the control group, while in the experimental group the activity of this enzyme increased by $39.5 \%$, respectively.

Thus, feeding piglets feed additive "Butaselmevit-plus" increased the activity of catalase in their blood throughout the experiment.

An important part of the antioxidant defense of animals is the glutathione system, which consists of enzymatic and non-enzymatic units. The non-enzymatic part of the gluta- thione system includes reduced glutathione, which is one of the most important physiological antioxidants. The normal course of a number of physiological and biochemical processes is due to the presence of glutamyl residue and reactive SH-group in GSH (Martyshuk et al., 2016).

On the 25th day of life in the blood of piglets of the control group found a slight increase in the content of reduced glutathione, while in the experimental group the content of reduced glutathione increased by $70 \%$ relative to the initial day (Fig. 3).

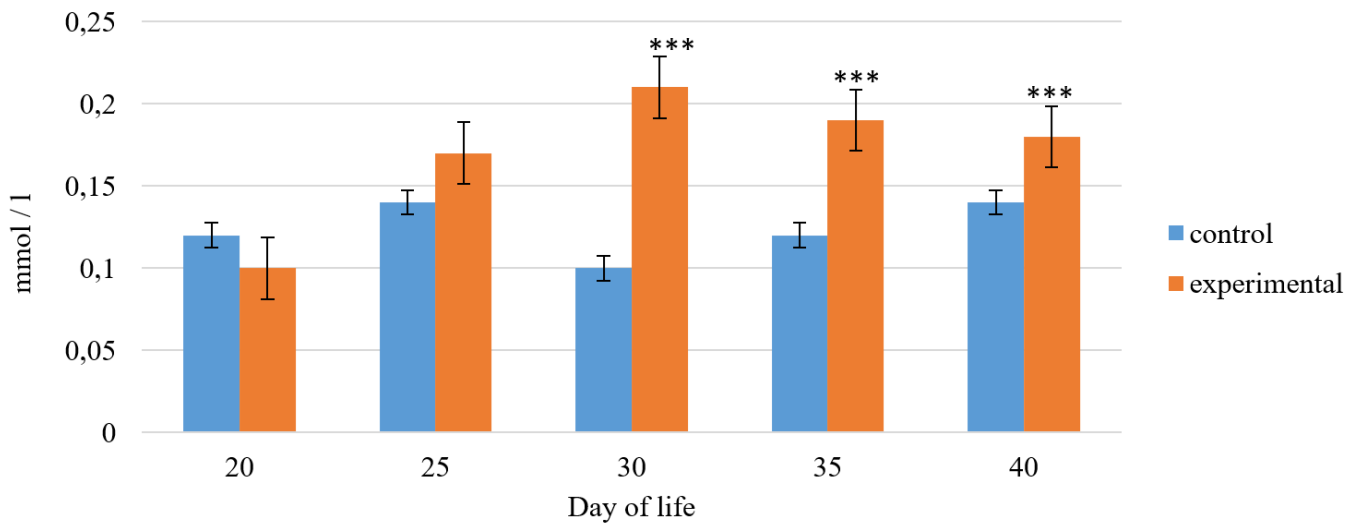

Fig. 3. The level of reduced glutathione in the blood of piglets under the action of feed additive "Butaselmevit-plus"

At 30 days of age, the control group of piglets showed a decrease in the studied indicator, while the experimental group of piglets fed with Butasselmevit-Plus feed increased the content of reduced glutathione in 2.1 times compared to the control group of piglets. In the 40-day-old piglets of the experimental group, the content of reduced glutathione remained at a high level compared with the control group, where it was correspondingly higher by $28.6 \%$.
Free glutathione with the participation of NADPH under the influence of glutathione peroxidase interacts with free radicals and inactivates their toxic effects due to oxidation of glutathione (Khariv et al., 2016; 2017). Oxidized glutathione is reduced under the influence of glutathione reductase, which is induced under the conditions of oxidative stress (Lavryshyn et al., 2016; Martyshuk, 2016; Ivankiv et al., 2019). 
It was found that in the blood of piglets of control and experimental groups, the activity of glutathione peroxidase in 20 -day-old piglets was 8.15 and $8.20 \mathrm{nmol} / \mathrm{min} \times \mathrm{mg}$ of protein (Fig. 4), while the activity of glutathione reductase 0.67 and $0.65 \mu \mathrm{mol} / \mathrm{min} \times \mathrm{mg}$ of protein (Fig. 5).
In the study of these enzymes in 25-day-old piglets, the activity of glutathione peroxidase increased by 16.3 and $18.3 \%$, and glutathione reductase - by 20.9 and $35.4 \%$ compared to the previous day of the study.

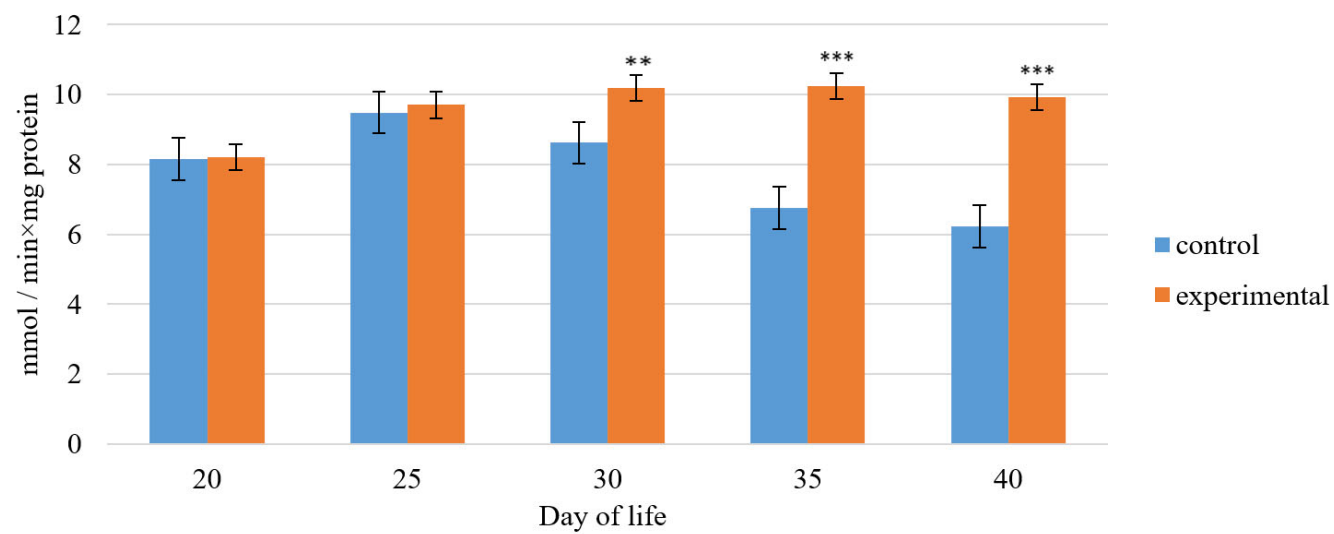

Fig. 4. Glutatine peroxidase activity in the blood of piglets under the action of feed additive "Butaselmevit-plus"

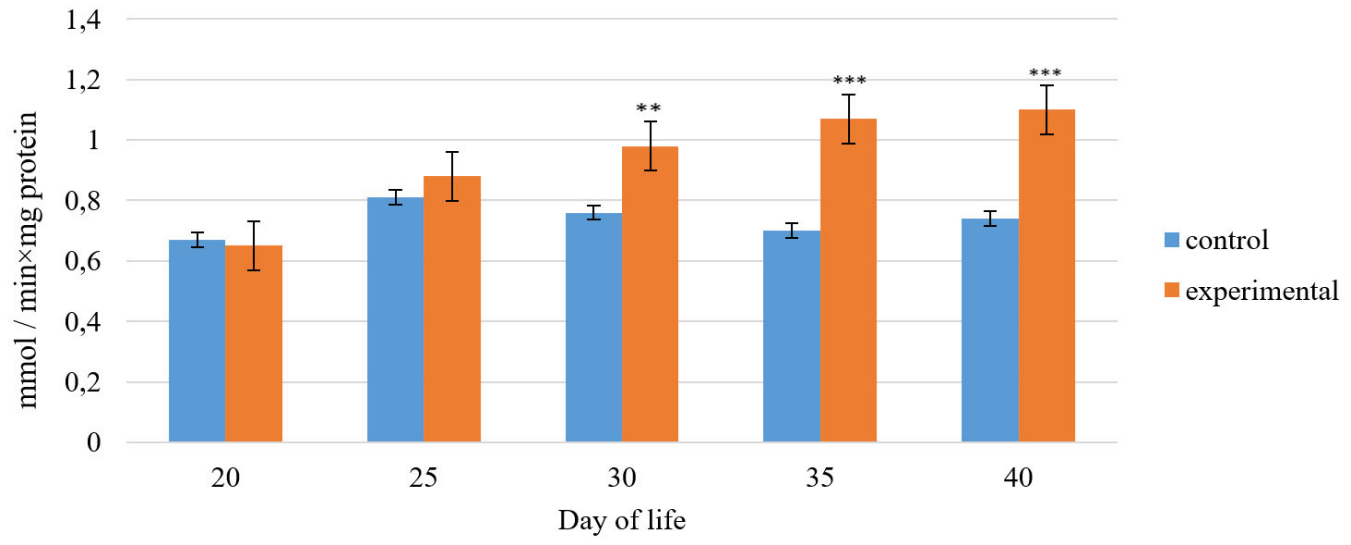

Fig. 5. Glutathione reductase activity in the blood of piglets under the action of feed additive "Butaselmevit-plus"

On the 30th day of life, the activity of glutathione peroxidase in the blood of the experimental group of piglets was higher by $18.1 \%$, and the activity of glutathione reductase by $28.9 \%$ relative to the control group of piglets.

In 35-day-old piglets of the control group we note the lowest activity of glutathione peroxidase and glutathione reductase, while in piglets of the experimental group, these figures were higher by 51.7 and $52.9 \%$, respectively.

Feeding the piglets of the experimental group of the feed additive "Butaselmevit-plus" enhanced the activity of the enzyme link of the glutathione system of antioxidant protection on the 40th day of life.

The highest glutathione reductase activity in the blood of 40-day-old piglets was in the experimental group, where it was correspondingly higher by $48.6 \%$ relative to the control group.

Thus, feeding piglets with feed additive "Butaselmevitplus" contributed to the activation of both enzymatic and non-enzymatic parts of the antioxidant defense system of piglets. This is due to the fact that the feed additive contains active substances such as milk thistle and vitamins, which are strong antioxidants of direct action and directly interact with free radicals and reactive oxygen species.

The data indicate that feeding piglets before weaning and after weaning feed additive "Butaselmevit-plus" helps to stabilize the antioxidant defense system, this is due to the presence of selenium and vitamins $\mathrm{A}$ and $\mathrm{E}$ in the drug and by increasing the activity of glutathione peroxidase - a key enzyme antioxidant system, which creates a second line of protection of cell membranes from the destructive effects of free radicals. Selenium protects cell membranes from free radical damage and also helps other antioxidants, and especially vitamin $\mathrm{E}$, to unleash their antioxidant potential (Frankic et al., 2010; Martyshuk et al., 2021). Selenium in glutathione peroxidase neutralizes the action of aggressive forms of oxygen formed in the processes of intensive lipid peroxidation (Sobolev et al., 2017; Nazaruk et al., 2021). The antioxidant effect of vitamin $\mathrm{A}$ is due to the conjugated double bonds in its molecule, due to which it interacts with free radicals of various types. Vitamin E, in turn, prevents the prooxidative properties of vitamin A by protecting its double bonds from oxidation and the formation of free radical products (Lavryshyn et al., 2016; Martyshuk \& Hutyi, 2019; Martyshuk \& Gutyi, 2019).

\section{Conclusions}

It was found that under conditions of technological stress, the use of feed additive "Butaselmevit-plus" in the amount of $100 \mathrm{mg} / \mathrm{kg}$ body weight per day improves the antioxidant defense of the body, as evidenced by the increase in blood 35 day-old piglets superoxide dismutase activity by $26.7 \%$ 
( $\mathrm{P}<0.001)$, catalase - by $39.5 \%(\mathrm{P}<0.001)$, glutathione peroxidase - by $51.7 \%(\mathrm{P}<0.05)$, glutathione reductase - by $52.9 \%(\mathrm{P}<0.05)$, the content of reduced glutathione - at $58.3 \%(\mathrm{P}<0.001)$.

\section{Conflict of interest}

The authors declare that there is no conflict of interest.

\section{References}

Ahmed, S. T., Hoon, J., Mun, H., \& Yang, C. (2014). Evaluation of Lactobacillus and Bacillus - based probiotics as alternatives to antibiotics in enteric microbial challenged weaned piglets. African Journal of Microbiology Research, 8(1), 96-104. doi: 10.5897/AJMR2013.6355.

Ariza-Nieto, C., Bandrick, M., Baidoo, S. K., Molitor, T. W., \& Hathaway, M. R. (2011). Effect of dietary supplementation of oregano essential oils to sows on colostrum and milk composition, growth pattern and immune status of suckling pigs. Journal of Animal Science, 89(4), 1079-1089. doi: 10.2527/jas.2010-3514.

Bulter, J., Sinkora, M., \& Wertz, N. (2006). Development of the neonatal $\mathrm{B}$ and $\mathrm{T}$ cell repertoire in swine: implications for comparative and veterinary immunology. Veterinary Research, 37(3), 417-441. doi: 10.1051/vetres:2006009.

Chen, X., Xu, J., Ren, E. Su, Y., \& Zhu, W. (2018). Co-occurrence of early gut colonization in neonatal piglets with microbiota in the maternal and surrounding delivery environments. Anaerobe, 49, 30-40. doi: 10.1016/j.anaerobe.2017.12.002.

Czech, A., Smolczyk, A., \& Ognik, K. (2018). Effect of dietary supplementation with Yarrowia lipolytica or Saccharomyces cerevisiae yeast and probiotic additives on haematological parameters and the gut microbiota in piglets. Research in Veterinary Science, 119, 221-227. doi: 10.1016/j.rvsc.2018.06.007.

De Lange, C., Pluske, J. R., Gong, J., \& Nyachoti, C. M. (2010). Strategic use of feed ingredients and feed additives to stimulate gut health and development in young pigs. Livestock Science, 134(1-3), 124-134. doi: 10.1016/j.livsci.2010.06.117.

Fedak, N., Chumachenko, S., Darmohray, L. M., Gutyj, B. V., \& Perederiy, M. H. (2018). The effectiveness of the use of probiotics for wet maize grain preserving. Scientific Messenger of Lviv National University of Veterinary Medicine and Biotechnologies, 20(89), 85-88. doi: 10.32718/nvlvet8916.

Frankic, T., Levart, A., \& Salobir, J. (2010). The effect of vitamin $\mathrm{E}$ and plant extract mixture composed of carvacrol, cinnamaldehyde and capsaicin on oxidative stress induced by high PUFA load in young pigs. Animal, 4(4), 572-578. doi: $10.1017 / \mathrm{S} 1751731109991339$.

Gutyj, B., Leskiv, K., Shcherbatyy, A., Pritsak, V., Fedorovych, V., Fedorovych, O., Rusyn, V., \& Kolomiiets, I. (2017). The influence of Metisevit on biochemical and morphological indicators of blood of piglets under nitrate loading. Regulatory Mechanisms in Biosystems, 8(3), 427-432. doi: 10.15421/021766

Gutyj, B., Martyshchuk, T., Bushueva, I., Semeniv, B., Parchenko, V., Kaplaushenko, A., Magrelo, N., Hirkovyy, A., Musiy, L., \& Murska, S. (2017). Morphological and biochemical indicators of blood of rats poisoned by carbon tetrachloride and subject to action of liposomal preparation. Regulatory Mechanisms in Biosystems, 8(2), 304-309. doi: 10.15421/021748.

Gutyj, B., Stybel, V., Darmohray, L., Lavryshyn, Y., Turko, I., Hachak, Y., Shcherbatyy, A., Bushueva, I., Parchenko, V., Kaplaushenko, A., \& Krushelnytska, O. (2017). Prooxidantantioxidant balance in the organism of bulls (young cattle) after using cadmium load. Ukrainian Journal of Ecology, 7(4), 589596.

Han, C., Dai,Y., Liu, B. Wang, L., Wang, J., \& Zhang, J. (2019). Diversity analysis of intestinal microflora between healthy and diarrheal neonatal piglets from the same litter in different regions. Anaerobe, 55, 136-141. doi: 10.1016/j.anaerobe.2018.12.001.

Hedemann, M. S., \& Jensen, B. B. (2004). Variations in enzyme activity in stomach and pancreatic tissue and digesta in piglets around weaning. Archives of Animal Nutrition, 58(1), 47-59. doi: 10.1080/00039420310001656677.

Heo, J. M., Opapeju, F. O., \& Kim, J. C. (2012). Gastrointestinal health and function in weaned pigs: a review of feeding strategies to control post-weaning diarrhoea without using in-feed antimicrobial compounds. Journal of Animal Physiology and Animal Nutrition, 97(2), 207-237. doi: 10.1111/j.14390396.2012.01284.x.

Holman, D. B., \& Chénierab, M. R. (2015). Antimicrobial use in swine production and its effect on the swine gut microbiota and antimicrobial resistance. Canadian Journal of Microbiology, 61(11), 785-798. doi: 10.1139/cjm-2015-0239.

Ivankiv, M., Kachmar, N., Mazurak, O., \& Martyshuk, T. (2019). Hepatic protein synthesis and morphological parameters in blood of rats under oxidative stress and action of feed additive "Butaselmevit-plus". Ukrainian Journal of Ecology, 9(4), 628-633. URL: $\quad$ https://www.ujecology.com/abstract/hepatic-proteinsynthesis-and-morphological-parameters-in-blood-of-rats-underoxidative-stress-and-action-of-feed-additi-44975.html.

Jacela, J. Y., DeRouchey, J. M., \& Tokach, M. D. (2010). Feed additives for swine: Fact sheets - prebiotics and probiotics, and phytogenics. Kansas Agricultural Experiment Station Research Reports, 18(3), 132-136. doi: 10.4148/2378-5977.7067.

Jayaraman, B., \& Nyachoti, C. M. (2017). Husbandry practices and gut health outcomes in weaned piglets: A review. Animal Nutrition, 3(3), 205-211. doi: 10.1016/j.aninu.2017.06.002.

Khalak, V., \& Gutyj, B. (2020). Physicochemical properties and chemical composition of muscle tissue of young pigs of large white breed and their correlation with some serum enzymes. Ukrainian Journal of Veterinary and Agricultural Sciences, 3(3), 34-38. doi: 10.32718/ujvas3-3.07.

Khalak, V., Gutyj, B., Bordun, O., Ilchenko, M., \& Horchanok, A. (2020). Effect of blood serum enzymes on meat qualities of piglet productivity. Ukrainian Journal of Ecology, 10(1), 158161. doi: 10.15421/2020 25 .

Khalak, V., Gutyj, B., Bordun, O., Horchanok, A., Ilchenko, M., Smyslov, S., Kuzmenko, O., \& Lytvyshchenko, L. (2020). Development and reproductive qualities of sows of different breeds: innovative and traditional methods of assessment. Ukrainian Journal of Ecology, 10(2), 356-360. doi: 10.15421/2020_109.

Khariv, M., Gutyj, B., Butsyak, V., \& Khariv, I. (2016). Hematological indices of rat organisms under conditions of oxidative stress and liposomal preparation action. Biological Bulletin of Bogdan Chmelnitskiy Melitopol State Pedagogical University, 6(1), 276-289. doi: 10.15421/201615.

Khariv, M., Gutyj, B., Ohorodnyk, N., Vishchur, O., Khariv, I., Solovodzinska, I., Mudrak, D., Grymak, C., \& Bodnar, P. (2017). Activity of the T- and B-system of the cell immunity of animals under conditions of oxidation stress and effects of the liposomal drug. Ukrainian Journal of Ecology, 7(4), 536-541. doi: 10.15421/2017 157 .

Kiczorowska, B., Samolinska, W., \& Al-Yasiry, A. R. M. (2017). The natural feed additives as immunostimulants in monogastric animal nutrition - a review. Annals of Animal Science, 17(3), 605-625. doi: 10.1515/aoas-2016-0076.

Kramarenko, S. S., Lugovoy, S. I., Kharzinova, V. R., Lykhach, V., Kramarenko, A. S., \& Lykhach, A. V. (2018). Genetic diversity of Ukrainian local pig breeds based on microsatellite markers. Regulatory Mechanisms in Biosystems, 9(2), 177182. doi: $10.15421 / 021826$.

Kramarenko, S., Lugovoy, S., Lykhach, A., Kramarenko, A., \& Lykhach, V. (2018). A comparative study of the reproductive traits and clustering analysis among different pig breeds. Scientific Messenger of LNU of Veterinary Medicine and Biotech-nologies. Series: Agricultural Sciences, 20(84), doi: $10.15421 /$ nvlvet 8404.

Kramarenko, S., Lugovoy, S., Lykhach, A., Kramarenko, A., Lykhach, V., \& Slobodianyk, A. (2019). Effect of genetic and non-genetic factors on the reproduction traits in Ukrainian Meat sows. Scientific Messenger of LNU of Veterinary Medi- 
cine and Biotechnologies. Series: Agricultural Sciences, 21(90), 3-8. doi: 10.32718/nvlvet-a9001.

Lavryshyn, Y. Y., Varkholyak, I. S., Martyschuk, T. V., Guta, Z. A., Ivankiv, L. B., Paladischuk, O. R., Murska, S. D., Gutyj, B. V., \& Gufriy, D. F. (2016). The biological significance of the antioxidant defense system of animals body. Scientific Messenger LNUVMBT named after S. Z. Gzhytskyj, 18(2(66), 100111. doi: $10.15421 /$ nvlvet6622.

Leskiv, Kh. Ya., Gufriy, D. F., Gutyj, B. V., Khalak, V. I., Hariv, I. I., Martyshuk, T. V., \& Guta, Z. A. (2021). The effect of methiphene, methionine, and phenarone on the humoral part of the immune System of piglets in experimental chronic nitratenitrite toxicosis. Colloquium-journal, 7(94), 12-15. doi: 10.24412/2520-6990-2021-794-12-15.

Lukashchuk, B. O., Slivinska, L. G., Shcherbatyy, A. R., Zinko, H. O., \& Gutyj, B. V. (2020). Influence of modern treatment regimens on serum biochemical parameters in piglets with gastroenteritis. Regulatory Mechanisms in Biosystems, 11(1), 67-73. doi: 10.15421/022009.

Lykhach, A. V., Lykhach, V. Y., Shpetny, M. B., Mykhalko, O. H., \& Zhyzhka, S. V. (2020). Influence of toys on behavioural patterns of pigs and their association with the concentration of serotonin in blood plasma. Regulatory Mechanisms in Biosystems, 11(1), 146-150. doi: 10.15421/022022.

Martyshuk, T. V. (2016). Vplyv oksydatsiinoho stresu na systemu antyoksydantnoho zakhystu orhanizmu shchuriv. Visnyk Dnipropetrovskoho universytetu. Biolohiia, medytsyna. Dnipro, 7(1), 8-12 (in Ukrainian).

Martyshuk, T. V., \& Gutyi, B. V. (2019). Influence of feed additive «Butaselmevit Plus» on the indicators of rats blood under the conditions of their poisoning with Tetrachloromethane. Theoretical and Applied Veterinary Medicine, 7(2), 79-83. doi: 10.32819/2019.71014.

Martyshuk, T. V., \& Hutyi, B. V. (2019). Morfolohichni pokaznyky krovi shchuriv za umov oksydatsiinoho stresu ta za dii kormovoi dobavky "Butaselmevit-plius". Naukovotekhnichnyi biuleten Derzhavnoho naukovo-doslidnoho kontrolnoho instytutu veterynarnykh preparativ ta kormovykh dobavok $i$ Instytutu biolohii tvaryn. Lviv, 20(2), 94-104 (in Ukrainian).

Martyshuk, T. V., \& Hutyi, B. V. (2021). Imunofiziolohichnyi stan ta antyoksydantnyi potentsial orhanizmu porosiat za umov oksydatsiinoho stresu ta dii koryhuiuchykh chynnykiv: monohrafiia. Lviv: SPOLOM (in Ukrainian).

Martyshuk, T. V., Gutyj, B. V., \& Vishchur, O. I. (2016). Level of lipid peroxidation products in the blood of rats under the influence of oxidative stress and under the action of liposomal preparation of "Butaselmevit". Biological Bulletin of Bogdan Chmelnitskiy Melitopol State Pedagogical University, 6(2), 22-27. doi: 10.15421/201631

Martyshuk, T. V., Gutyj, B. V., Leskiv, Kh. Ya., Semaniuk, N. V., \& Shnaider, V. L. (2021). The effect of the liposomal drug "butaselmevit" on the enzymatic and non-enzymatic part of the glutatoin system of the blood of rats under oxidative stress. Colloquium-journal, 12(99), 16-19.

Martyshuk, T. V., Gutyj, B. V., Zhelavskyi, M. M., Midyk. S. V., Fedorchenko, A. M., Todoriuk, V. B., Nahirniak, T. B., Kisera, Ya. V., Sus, H. V., Chemerys, V. A., Levkivska, N. D., \& Iglitskej, I. I. (2020). Effect of Butaselmevit-Plus on the immune system of piglets during and after weaning. Ukrainian Journal of Ecology, 10(2), 347-352. doi: 10.15421/2020 106.

Martyshuk, T. V., Hutyi, B. V., Khalak, V. I., Stadnytska, O. I., \& Todoriuk, V. B. (2019). Stan imunnoi systemy porosiat za dii kormovoi dobavky "Butaselmevit-plius". Visnyk Poltavskoi derzhavnoi ahrarnoi akademii, 4, 116-125. doi: 10.31210/visnyk2019.04.14 (in Ukrainian).

Martyshuk, T., Gutyj, B., Vishchur, O., \& Todoriuk, V. (2019). Biochemical indices of piglets blood under the action of feed additive "Butaselmevit-plus". Ukrainian Journal of Veterinary and Agricultural Sciences, 2(2), 27-30. doi: 10.32718/ujvas22.06 .

Masiuk, D. M., Sosnitsky, O. I., Nedzvetsky, V. S., Kokarev, A. V., \& Koliada, S. G. (2017). Epidemiology, etiology and gene analysis of spike $\mathrm{S}$ protein of porcine epidemic diarrhea virus infection in Ukraine during 2016-2017. Regulatory Mechanisms in Biosystems, 8(4), 602-610. doi: 10.15421/021792.

Masiuk, D. N., Nedzvetsky, V. S., Sosnitskiy, A. I., Kokarev, A. V., \& Koliada, S. G. (2018). The characteristics, emergent properties and manner of spread in Ukraine of the Porcine Epidemic Diarrhea Virus. Regulatory Mechanisms in Biosystems, 9(3), 401-408. doi: 10.15421/021860.

Nazaruk, N. V., Gutyj, B. V., Gufrij, D. F., Leskiv, Kh. Ya., Ivashkiv, R. M., \& Martyshuk, T. V. (2021). The effect of methyphen and vitamix se on the level of products of bull lipid peroxide oxidation under nitrate-cadmium load. Colloquiumjournal, 7(94), 16-18. doi: 10.24412/2520-6990-2021-794-1618.

Sachuk, R., Stravskyy, Y., Gutyj, B., Velesyk, T., Katsaraba, O., \& Zhyhaliuk, S. (2021). Study of acute toxicity of the drug "Kolidev 8M" with a single intragastric injection in laboratory animals. ScienceRise: Biological Science, 2(27), 44-48. doi: 10.15587/2519-8025.2021.235952.

Slobodian, S. O., Gutyj, B. V., Darmohray, L. M., \& Povoznikov, M. G. (2021). Antioxidant status of the organisms of young bulls in the conditions of lead-cadmium load and effect of correcting factors. Regulatory Mechanisms in Biosystems, 12(2), 315-320. doi: 10.15421/022142.

Snegin, E. A., Kramarenko, A. S., Artemchuk, O. Y., \& Kramarenko, S. S. (2021). Intra- and interbreed genetic heterogeneity and divergence in four commercial pig breeds based on microsatellite markers. Regulatory Mechanisms in Biosystems, 12(1), 128-135. doi: 10.15421/022120.

Sobolev, A., Gutyj, B., Grynevych, N., Bilkevych, V., \& Mashkin, Y. (2017). Enrichment of meat products with selenium by its introduction to mixed feed compounds for birds. Regulatory Mechanisms in Biosystems, 8(3), 417-422. doi: 10.15421/021764.

Stoyanovskyy, V., Usenko, S., Shostya, A., Kuzmenko, L., Slynko, V., \& Tenditnyk, V. (2020). Hormonal regulation of prooxidant-antioxidant homeostasis in gilts. Ukrainian Journal of Veterinary and Agricultural Sciences, 3(3), 39-43. doi: 10.32718/ujvas3-3.08.

Stybel, V. V., Gutyj, B. V., Said, W. S., Kubiak, K., Jankowski M., Maksymovych, I. A., Guta, Z. A., Martyshuk, T. V., \& Karpovskiy, V. I. (2021). The effect of fenbensyl and fenbendazole on the antioxidant status of dogs during experimental invasion with the pathogen toxocariasis. Ukrainian Journal of Veterinary Sciences, 12(2). URL: http://journals.nubip.edu.ua/index.php/ Veterenarna/article/view/15141

Varkholiak, I. S., Gutyj, B. V., Leskiv, Kh. Ya., Kushnir, V. I., Hariv, I. I., Martyshuk, T. V., \& Guta, Z. A. (2021). The effect of bendamine on antioxidant protection of rats' myocardium in doxorubicin intoxication. Colloquium-journal, 7(94), 18-21. doi: 10.24412/2520-6990-2021-794-18-21.

Vasylyev, D., Priimenko, B., Aleksandrova, K., Mykhalchenko, Y., Gutyj, B., Mazur, I., Magrelo, N., Sus, H., Dashkovskyy, O., Vus, U., \& Kamratska, O. (2021). Investigation of the acute toxicity of new xanthine xenobiotics with noticeable antioxidant activity. Ukrainian Journal of Ecology, 11(1), 315-318. doi: 10.15421/2021_47. 